\title{
Pengembangan Media Pembelajaran Powtoon Berbasis Pendekatan Saintifik Pada Mata Pelajaran Ekonomi
}

\author{
Maya Masitha Fardany \\ Program Studi Pendidikan Ekonomi, Fakultas Ekonomi, Universitas Negeri Surabaya \\ e-mail: mayafardany16080554070@mhs.unesa.ac.id \\ Retno Mustika Dewi \\ Program Studi Pendidikan Ekonomi, Fakultas Ekonomi, Universitas Negeri Surabaya \\ e-mail: retnomustika@unesa.ac.id
}

\begin{abstract}
Abstrak
Media memiliki peran yang penting dalam proses pembelajaran, sehingga pemilihan media harus didasarkan pada karakteristik materi dan peserta didik. Akan tetapi pada sekolah tempat penelitian, pemilihan media kurang sesuai dengan karakteristik dari peserta didik dan karakteristik materi bank sentral dan sistem pembayaran. Tujuan penelitian ini adalah untuk mendeskripsikan kelayakan, kepraktisan, dan keefektifan media pembelajaran powtoon berbasis pendekatan saintifik pada mata pelajaran ekonomi. Jenis penelitian ini merupakan penelitian Research and Development (R\&D) dengan menerapkan model pengembangan 4D dari Thiagarajan, meliputi pendefinisian, perancangan, pengembangan, dan penyebaran. Desain penelitian menggunakan One Grup Pretest-Posttest Design. Subjek uji coba penelitian merupakan peserta didik kelas X IPS 2 MAN Sidoarjo sebanyak 20 orang. Instrumen pengumpulan data menggunakan 1) lembar telaah dan validasi materi, media, dan bahasa, 2) angket respon peserta didik, 3) soal pretest dan posttest. Adapun dari hasil penelitian diperoleh bahwa: 1) pengembangan media pembelajaran powtoon dinyatakan layak dengan perolehan persentase validasi materi $80 \%$, validasi media $81,18 \%$, dan validasi bahasa $94 \%$ sehingga media dinyatakan layak digunakan sebagai media pembelajaran, 2) hasil angket respon peserta didik memperoleh persentase sebesar 95,5\% sehingga media dinyatakan praktis digunakan sebagai media pembelajaran, 3) hasil belajar peserta didik memperoleh persentase ketuntasan sebesar $90 \%$, hasil tersebut merupakan peningkatan daripada hasil pretest yang memiliki persentase ketuntasan sebesar 55\% saja, sehingga media dinyatakan efektif digunakan sebagai media pembelajaran. Dengan demikian diperoleh kesimpulan bahwa media pembelajaran powtoon berbasis pendekatan saintifik pada mata pelajaran ekonomi dinyatakan layak, praktis, dan efektif untuk digunakan sebagai media pembelajaran.
\end{abstract}

Kata Kunci: powtoon; media pembelajaran; pendekatan saintifik; ekonomi

\begin{abstract}
The media has an important role in the learning process, so the selection of media must be based on the characteristics of the material and students. But at the school where the research, media selection was not in accordance with the characteristics of the students and the characteristics of the central bank's and payment system material. The purpose of this study is to describe the feasibility, practicality, and effectiveness of the media learning powtoon based on a scientific approach to economic subjects. This type of research is Research and Development (R\&D) by applying the 4D development model from Thiagarajan, including define, design, develop, and disseminate. The research design using One Group Pretest-Posttest Design. The subjects of this research were 20 students of class X IPS 2 MAN Sidoarjo. Data collection instruments using 1) study sheets and validation of material, media and language, 2) questionnaire responses of students, 3) questions of pretest and posttest. As for the results of the study it was found that: 1) the development of Powtoon learning media was declared feasible with the acquisition of material validation percentage of $80 \%$, media validation of $81.18 \%$, and language validation of $94 \%$ so that the media was declared feasible to be used as a learning media, 2) the results student questionnaire responses have a percentage of $95.5 \%$ so that the media declared practical to be used as a learning media, 3) student learning outcomes have a percentage of completeness by $90 \%$, these results are an increase compared to the results of the pretest which has a percentage of completeness by $55 \%$ only, so that the media are declared effective for use as learning media. Thus it was concluded that the media learning powtoon based on a scientific approach to economic subjects was declared feasible, practical, and effective for use as a learning media.
\end{abstract}

Keywords: powtoon; learning media; scientific approach; economics 


\section{PENDAHULUAN}

Teknologi yang semakin maju menuntut seorang guru untuk selalu mengembangkan potensi yang dimilikinya, misalnya dengan memiliki keterampilan pada bidang ilmu pengetahuan dan teknologi dalam pembelajaran. Peran seorang guru didalam pembelajaran saat ini adalah sebagai fasilitator, yaitu bertugas memfasilitasi pembelajaran dengan memberikan kemudahan belajar kepada seluruh peserta didik di dalam kelas agar mereka berani mengemukakan pendapat dan aktif berpartisipasi dalam kegiatan pembelajaran (Mulyasa 2013). Oleh karena itu dibutuhkan inovasi baru yang menarik untuk pengajaran. Salah satu inovasi tersebut dapat diterapkan melalui media, contohnya yaitu video pembelajaran. Video merupakan media yang paling efektif untuk menyampaikan sebuah informasi. Penerapan video dalam pembelajaran dapat memberikan sebuah pengalaman baru. Selain itu peserta didik akan menjadi lebih tertarik dengan presentasi yang ditayangkan dalam bentuk video (Munir 2012).

Berdasarkan hasil dari studi pendahuluan, diperoleh data bahwa terdapat lima kelas IPS di MAN Sidoarjo. Diantara lima kelas tersebut, terdapat satu kelas yaitu kelas X IPS 2 dengan nilai Penilaian Tengah Semester (PTS) pelajaran ekonomi lebih rendah yaitu sebesar 56,22 sedangkan nilai Ketuntasan Belajar Minimal (KBM) sekolah adalah 80. Sehingga peneliti tertarik untuk memilih kelas X IPS 2 sebagai kelas ujicoba dengan jumlah peserta didik 20 orang yang memiliki kemampuan heterogen.

Perolehan hasil belajar yang rendah disebabkan karena kurangnya pemahaman materi oleh peserta didik. Selama ini peserta didik hanya mengandalkan guru atau pengajar sebagai satu-satunya sumber pembelajaran sehingga peserta didik kurang termotivasi dalam menggali informasi dari berbagai sumber dan hanya bergantung kepada informasi yang disampaikan oleh guru, sehingga peserta didik memiliki sumber pengetahuan yang minim dan kemampuan berpikir kritis yang kurang.

Selain itu, hasil dari wawancara bersama guru ekonomi kelas $\mathrm{X}$ menjelaskan bahwa pembelajaran ekonomi pada umumnya diajarkan menggunakan media power point, akan tetapi media tersebut lebih dominan dengan tulisan (power text) dan desain power point kurang menonjolkan variasi warna, gambar, dan visual sehingga kurang menarik. Hal tersebut membuat peserta didik banyak menemui kesulitan untuk memahami materi dan seringkali merasa bosan ketika diterangkan, padahal di sekolah tersebut memiliki fasilitas pembelajaran yang menunjang seperti LCD, proyektor, serta sound system di masing-masing kelas.
Peneliti memilih materi bank sentral dan sistem pembayaran karena materi ini memiliki banyak teori. Apabila materi ini disampaikan dengan metode ceramah dan media power point yang berisi power text, maka akan membuat peserta didik menjadi mudah bosan dan materi tidak bisa tersampaikan dengan baik sehingga hal tersebut bisa berpengaruh dalam perolehan hasil belajar (Ariyanto, Kantun, dan Sukidin 2018).

Dari permasalahan tersebut, maka perlu adanya suatu media pembelajaran yang inovatif dan menarik serta berfungsi untuk menyampaikan materi bank sentral dan sistem pembayaran. Hal ini dapat dilakukan dengan merangkum poin-poin penting yang dikemas dengan animasi dan suara yang menarik, sehingga akan melibatkan peserta didik menjadi lebih aktif selama kegiatan pembelajaran serta diharapkan meningkatkan hasil belajar. Dari hasil analisis tersebut, peneliti memilih mengembangkan media pembelajaran powtoon berbasis pendekatan saintifik.

Powtoon merupakan software yang diakses secara online berfungsi untuk membuat video dan memiliki fitur yang menarik yaitu animasi kartun, efek transisi, berbagai macam tulisan, dan juga pengaturan timeline yang mudah. Menurut Dwyer dalam (Sadiman, 1996), video dapat menarik $94 \%$ informasi dan pesan melalui telinga dan mata serta membuat orang untuk mampu mengingat sebesar 50\% dari sesuatu yang mereka dengar dan lihat terhadap sebuah tayangan (Mamin, Nur, dan Arif n.d.).

Powtoon mempunyai banyak pilihan animasi yang menarik untuk digunakan dalam menyampaikan isi materi pembelajaran dalam bentuk video (Ponza, Jampel, dan Sudarma 2018). Dalam dunia pembelajaran, media belajar yang menggunakan software powtoon masih jarang diterapkan. Padahal media ini bisa menjadi altenatif perkembangan teknologi untuk diterapkan terhadap materi yang di anggap sulit menurut peserta didik menjadi lebih menyenangkan dan menarik, hal tersebut karena penyajian media menggunakan unsur audio dan visual (Sari dan Rohayati 2016).

Kelebihan yang dimiliki dari media Powtoon antara lain yaitu adanya fitur animasi yang beraneka macam, efek transisi yang menarik, serta timeline pada aplikasi yang dapat diatur dengan lebih mudah apabila dibandingkan dengan aplikasi lainnya yang sejenis (Ernalida et al. 2018). Selain itu, powtoon mudah digunakan karena hasil akhirnya berupa video, serta tersedia berbagai pilihan animasi yang sudah terdapat pada aplikasi powtoon, sehingga guru hanya perlu memilih tanpa harus membuat animasi dengan cara manual. Berbagai macam animasi tersebut dapat menunjang pembuatan video pembelajaran menjadi lebih menarik. (Ponza, Jampel, dan Sudarma 2018). 
Media pembelajaran powtoon yang dikembangkan menerapkan pendekatan saintifik dan didalamnya terdapat soal pernyataan pada video pembelajaran. Soal ini bertujuan agar peserta didik ikut aktif terlibat selama proses belajar mengajar. Media ini juga berisi gambar, animasi, teks bergerak, musik, dan suara rekaman penjelasan materi Media pembelajaran menggunakan powtoon masih belum pernah digunakan sebagai media pembelajaran ekonomi khususnya di MAN Sidoarjo. Sehingga hal ini dapat digunakan sebagai altenatif media pembelajaran yang menggunakan perkembangan teknologi untuk materi yang dianggap peserta didik sulit dan membosankan menjadi lebih mudah dan menyenangkan karana ditampilkan melalui audio dan visual yang menarik bagi peserta didik.

Berdasarkan penelitian terdahulu oleh Pangestu dan Wafa (2018) menjelaskan bahwa pengembangkan multimedia interaktif powtoon dinyatakan layak. Hal tersebut diperoleh berdasarkan penilaian dari ahli media, ahli materi, dan angket respon peserta didik yang membuktikan bahwa multimedia interaktif powtoon dapat memotivasi peserta didik dalam belajar. Penelitian lain oleh Sari dan Rohayati (2016) menyatakan bahwa media pembelajaran powtoon sangat layak untuk diterapkan pada materi dasar-dasar perbankan. Hal tersebut diperoleh dari rata-rata keseluruhan nilai validasi media pembelajaran powtoon yaitu sebesar $91 \%$. Berdasarkan penelitian terdahulu tersebut, didapatkan kesimpulan bahwa media pembelajaran powtoon layak untuk diterapkan menjadi media pembelajaran.

Sehingga dari latar belakang di atas, peneliti bertujuan untuk mendeskripsikan kelayakan, kepraktisan, dan keefektifan media pembelajaran powtoon berbasis pendekatan saintifik pada mata pelajaran ekonomi.

\section{METODE}

Jenis penelitian ini yaitu $R \& D$ atau penelitian dan pengembangan. Peneliti menerapkan model pengembangan 4D dari Thiagarajan (Trianto 2007) yang meliputi 4 tahapan yakni pendefinisian, perancangan, pengembangan, dan penyebaran.

Desain ujicoba penelitian menggunakan One Group Pretest-Postest Design. Didalam penerapannya dilaksanakan pretest kepada peserta didik sebelum pemberian perlakuan, kemudian dilakukan posttest setelah ada perlakuan.

Subjek ujicoba dalam penelitian ini merupakan peserta didik kelas X IPS 2 MAN Sidoarjo berjumlah sebanyak 20 orang yang dapat mewakili dan mencerminkan karakteristik populasi. Pengambilan sampel dilakukan secara acak dalam penelitian ujicoba terbatas. Menurut (Sadiman et al. 2014) dalam melakukan ujicoba terbatas, peserta didik yang digunakan sebagai subjek penelitian adalah sebanyak 10 - 20 orang.

Instrumen pengumpulan data yaitu berupa data kualitatif dan data kuantitatif. Untuk data kualitatif didapatkan melalui lembar telaah berupa saran dan komentar para ahli yang digunakan untuk memperbaiki media pembelajaran. Untuk data kuantitatif didapatkan melalui lembar validasi, angket respon peserta didik, dan soal pretest dan posttest. Data kelayakan produk didapatkan dari lembar validasi yang diserahkan ke ahli materi, ahli media dan ahli bahasa untuk dilakukan validasi produk menggunakan skala likert, sehingga dapat diketahui kelayakan media pembelajaran. Data kepraktisan produk didapatkan melalui hasil angket dari respon peserta didik menggunakan skala guttman, sehingga dapat diketahui kepraktisan media pembelajaran. Data keefektifan produk didapatkan dari nilai pretest posttest peserta didik, selanjutnya dapat diketahui keefektifan media pembelajaran.

Teknik analisis data validasi dan respon peserta didik menggunakan kriteria interpretasi skor skala likert. Hal tersebut dapat dilihat pada tabel di bawah ini:

Tabel 1. Kriteria Interpretasi Skor

\begin{tabular}{cc}
\hline Skor & Kriteria \\
$81 \%-100 \%$ & Sangat Layak \\
$61 \%-80 \%$ & Layak \\
$41 \%-60 \%$ & Cukup Layak \\
$21 \%-40 \%$ & Tidak Layak \\
$0 \%-20 \%$ & Sangat Tidak Layak \\
\hline \multicolumn{2}{c}{ Sumber: }
\end{tabular}

Berdasarkan tabel kriteria interpretasi skor di atas, kriteria didapatkan berdasarkan skor yang diperoleh. Perolehan skor dalam rentang $81 \%$ hingga $100 \%$ dapat dikatakan sangat layak, perolehan skor dalam rentang $61 \%$ hingga $80 \%$ dapat dikatakan layak, perolehan skor dalam rentang $41 \%$ hingga $60 \%$ dapat dikatakan cukup layak, perolehan skor dalam rentang 21\% hingga $40 \%$ dikatakan tidak layak, dan perolehan skor dalam rentang 0\% hingga 20\% dikatakan sangat tidak layak.

Sedangkan pada teknik analisis data hasil belajar peserta didik, peneliti menggunakan kriteria ketuntasan klasikal seperti pada tabel di bawah ini:

\begin{tabular}{cc} 
Tabel 2. Kriteria & Ketuntasan Klasikal \\
\hline Persentase & Kriteria Interpretasi \\
$<75 \%$ & Tidak Tuntas \\
$\geq 75 \%$ & Tuntas \\
\hline
\end{tabular}

Sumber : (Syifaunnur 2015)

Tabel tersebut menunjukkan kriteria ketuntasan klasikal yang digunakan peneliti dalam menganalisis 
perolehan data hasil belajar peserta didik. Dalam perhitungannya apabila persentase jumlah peserta didik yang mencapai nilai di atas KBM sebanyak kurang dari 75\% maka ketuntasan klasikal dapat dikatakan tidak tuntas, dan sebaliknya apabila persentase jumlah peserta didik yang mencapai nilai diatas KBM sebanyak lebih dari sama dengan $75 \%$ maka ketuntasan klasikal dapat dikatakan tuntas.

\section{HASIL DAN PEMBAHASAN \\ Hasil Penelitian}

Penelitian ini akan menghasilkan media pembelajaran powtoon berbasis pendekatan saintifik dengan menerapkan model pengembangan 4D oleh Thiagarajan. Tahap awal merupakan pendefinisian (define): a) analisis awal yaitu pemilihan media dalam pembelajaran ekonomi di sekolah tempat penelitian kurang sesuai dengan karakteristik materi dan peserta didik, b) analisis peserta didik dilakukan terhadap peserta didik kelas X IPS 2 MAN Sidoarjo, c) analisis tugas peserta didik terdapat 3 bagian. Pertama pertanyaan yang terdapat pada video pembelajaran powtoon, berbentuk pernyataan singkat kemudian peserta didik menjawab secara bersama-sama apakah pernyataan tersebut benar atau salah. Kedua pertanyaan studi kasus dari hasil pengamatan video. Ketiga pertanyaan pretest dan posttest berbentuk soal pilihan ganda yang disesuaikan dengan tingkat berpikir peserta didik, d) analisis konsep yakni menggunakan KD 3.6 yaitu bank sentral dan sistem pembayaran dalam perekonomian indonesia, e) analisis tujuan pembelajaran disesuaikan dengan tujuan indikator bank sentral dan sistem pembayaran.

Tahap kedua merupakan perancangan (design): a) penyusunan tes, dimana peneliti melakukan penyusunan pretest dan posttest dengan soal yang berbentuk pilihan ganda berdasarkan kisi-kisi soal yang sudah dibuat sebelumnya, b) pemilihan media, yaitu menggunakan software powtoon yang dibuat secara online dan menyediakan bermacam fitur yang menarik yang mudah untuk divariasikan sesuai dengan kreativitas, c) pemilihan format media ini adalah video yang berisi materi pembelajaran, soal dan jawaban, serta studi kasus yang sesuai dengan fenomena terkini dengan menggunakan pendekatan saintifik d) desain awal berupa rancangan awal media, selanjutnya akan divalidasi/dinilai oleh para ahli agar media pembelajaran powtoon menjadi lebih sempurna.

Tahap ketiga merupakan pengembangan (develop), hasil dari rancangan awal media yang telah disusun selanjutnya ditelaah oleh dosen ahli materi, ahli media, dan ahli bahasa. Kemudian peneliti memperbaiki media berdasarkan komentar dan saran yang diberikan oleh para ahli. Berikut merupakan beberapa perbaikan dari media pembelajaran powtoon:

Tabel 3. Revisi Media Powtoon

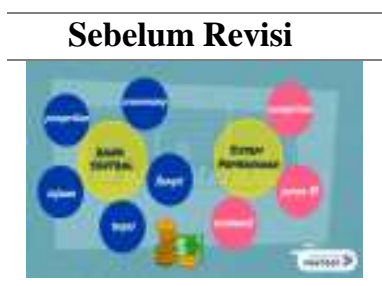
Sesudah Revisi

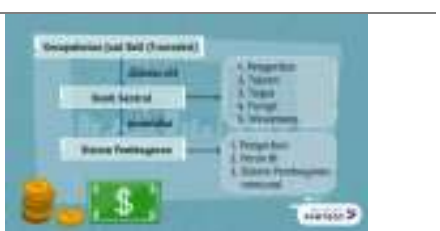

Peta konsep menjadi lebih sistematis
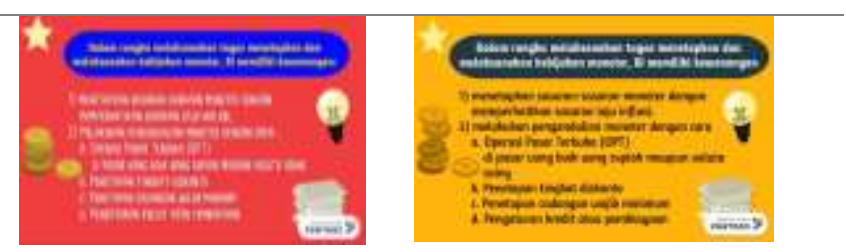

Font dapat terbaca dengan jelas

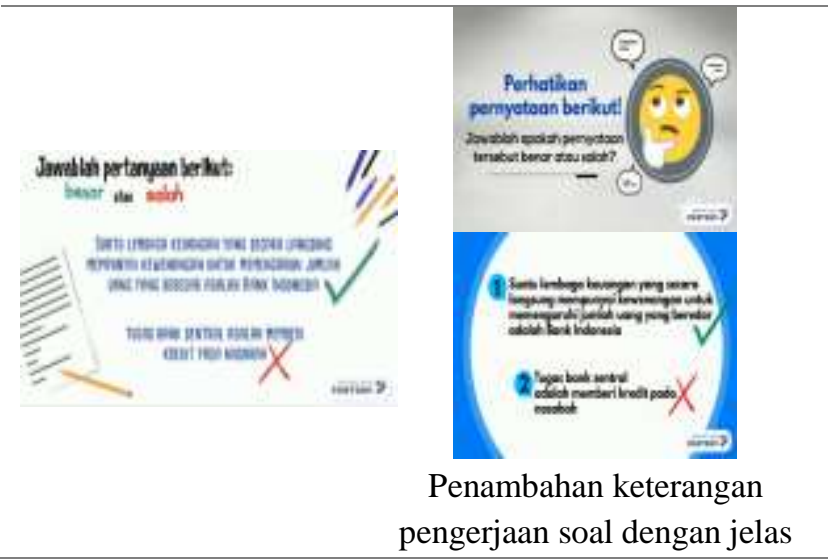

Sumber: diolah peneliti (2020)

Tabel tersebut menunjukkan bahwa terdapat beberapa perbaikan pada media pembelajaran powtoon antara lain perbaikan pada peta konsep sehingga menjadi lebih sistematis, perbaikan pada warna dan font agar peserta didik dapat membaca materi dengan jelas, dan perbaikan penambahan keterangan pengerjaan soal agar lebih jelas.

Setelah direvisi, media powtoon akan divalidasi oleh para ahli terlebih dahulu sebelum dilakukan ujicoba kepada peserta didik. Di bawah ini merupakan data perolehan hasil validasi:

Tabel 4. Hasil Validasi

\begin{tabular}{ccc}
\hline Aspek & $\begin{array}{c}\text { Rata-Rata Hasil } \\
\text { Keseluruhan }\end{array}$ & Kategori \\
Materi & $80 \%$ & Layak \\
Media & $81,18 \%$ & Sangat Layak \\
Bahasa & $94 \%$ & Sangat Layak \\
$\overline{\boldsymbol{X}}$ & $85,06 \%$ & Sangat Layak \\
\hline \multicolumn{3}{c}{ Sumber: diolah peneliti (2020) }
\end{tabular}


Tabel di atas merupakan perolehan hasil validasi materi, media, dan bahasa. Perolehan rata-rata validasi materi yaitu $80 \%$ dalam kategori layak, perolehan rata-rata validasi media yaitu $81,18 \%$ dalam kategori sangat layak, perolehan rata-rata validasi bahasa yaitu $94 \%$ dalam kategori sangat layak, dan perolehan jumlah rata-rata keseluruhan hasil validasi adalah $85,06 \%$ dalam kategori sangat layak.

Setelah dinyatakan layak dalam perolehan hasil validasi materi, media, dan bahasa maka tahap berikutnya yaitu dilakukan ujicoba produk. Uji coba produk dilakukan dalam dua tahap, yaitu tahap sebelum dan sesudah menggunakan media pembelajaran powtoon. Pada tahap sebelum menggunakan media powtoon, peserta didik diberikan soal pretest berbentuk pilihan ganda. Berikut merupakan perolehan data hasil pretest:

\section{Tabel 5. Hasil Pretest}

\begin{tabular}{ccc}
\hline Nilai & Frekuensi & Keterangan \\
$\mathbf{0}-\mathbf{1 0}$ & 0 & Tidak Tuntas \\
$\mathbf{1 1}-\mathbf{2 0}$ & 0 & Tidak Tuntas \\
$\mathbf{2 1}-\mathbf{3 0}$ & 0 & Tidak Tuntas \\
$\mathbf{3 1}-\mathbf{4 0}$ & 1 & Tidak Tuntas \\
$\mathbf{4 1}-\mathbf{5 0}$ & 1 & Tidak Tuntas \\
$\mathbf{5 1}-\mathbf{6 0}$ & 3 & Tidak Tuntas \\
$\mathbf{6 1}-\mathbf{7 0}$ & 4 & Tidak Tuntas \\
$\mathbf{7 1}-\mathbf{8 0}$ & 8 & Tuntas \\
$\mathbf{8 1}-\mathbf{9 0}$ & 3 & Tuntas \\
$\mathbf{9 1}-\mathbf{1 0 0}$ & 0 & Tuntas \\
$\mathbf{\%}$ ketuntasan & $\mathbf{5 5 \%}$ & Tidak Tuntas \\
\hline
\end{tabular}

Sumber : diolah peneliti (2020)

Tabel tersebut menunjukkan jumlah peserta didik yang tuntas yaitu 55\% atau sebanyak 11 orang, dengan perolehan nilai terendah 40 dan perolehan nilai tertinggi 90 .

Tahap selanjutnya adalah sesudah menggunakan media pembelajaran powtoon. Pada tahap ini peserta didik diminta untuk mengerjakan soal posttest berbentuk pilihan ganda. Berikut merupakan perolehan data hasil posttest:

Tabel 6. Hasil Posttest

\begin{tabular}{ccc}
\hline Nilai & Frekuensi & Keterangan \\
$\mathbf{0}-\mathbf{1 0}$ & 0 & Tidak Tuntas \\
$\mathbf{1 1}-\mathbf{2 0}$ & 0 & Tidak Tuntas \\
$\mathbf{2 1}-\mathbf{3 0}$ & 0 & Tidak Tuntas \\
$\mathbf{3 1}-\mathbf{4 0}$ & 0 & Tidak Tuntas \\
$\mathbf{4 1}-\mathbf{5 0}$ & 0 & Tidak Tuntas \\
$\mathbf{5 1}-\mathbf{6 0}$ & 1 & Tidak Tuntas \\
\hline
\end{tabular}

\begin{tabular}{ccc}
\hline $\mathbf{6 1}-\mathbf{7 0}$ & 1 & Tidak Tuntas \\
$\mathbf{7 1}-\mathbf{8 0}$ & 2 & Tuntas \\
$\mathbf{8 1}-\mathbf{9 0}$ & 8 & Tuntas \\
$\mathbf{9 1}-\mathbf{1 0 0}$ & 8 & Tuntas \\
\% ketuntasan & $\mathbf{9 0 \%}$ & Tuntas \\
\hline
\end{tabular}

Sumber : diolah peneliti (2020)

Tabel tersebut menunjukkan jumlah peserta didik yang tuntas yaitu 90\% atau sebanyak 18 orang, dengan perolehan nilai terendah 60 dan perolehan nilai tertinggi 100 .

Setelah mengerjakan soal posttest, peserta didik mengisi angket respon yang telah disediakan terkait dengan kesan atau ketertarikan mereka pada media pembelajaran powtoon. Selanjutnya hasil angket respon peserta didik dilakukan analisis berdasarkan skala guttman, skor 1 pada jawaban Ya dan skor 0 pada jawaban Tidak. Perolehan hasil respon peserta didik terdapat pada tabel di bawah ini:

Tabel 7. Hasil Respon Peserta Didik

\begin{tabular}{ccc}
\hline Aspek & $\begin{array}{c}\text { Persen } \\
\text { tase }(\boldsymbol{\%})\end{array}$ & Kategori \\
$\mathbf{1}$ & $100 \%$ & Sangat Layak \\
$\mathbf{2}$ & $100 \%$ & Sangat Layak \\
$\mathbf{3}$ & $85 \%$ & Sangat Layak \\
$\mathbf{4}$ & $80 \%$ & Layak \\
$\mathbf{5}$ & $90 \%$ & Sangat Layak \\
$\mathbf{6}$ & $100 \%$ & Sangat Layak \\
$\mathbf{7}$ & $100 \%$ & Sangat Layak \\
$\mathbf{8}$ & $100 \%$ & Sangat Layak \\
$\mathbf{9}$ & $100 \%$ & Sangat Layak \\
$\mathbf{1 0}$ & $100 \%$ & Sangat Layak \\
$\overline{\boldsymbol{X}}$ & $\mathbf{9 5 , 5 \%}$ & Sangat Layak \\
\hline \multicolumn{3}{l}{ Sumber : diolah peneliti (2020) }
\end{tabular}

Berdasarkan tabel tersebut, total rata-rata keseluruhan hasil angket dari respon peserta didik kelas X IPS 2 MAN Sidoarjo yaitu sebesar 95,5\% dalam kategori sangat layak. Sehingga diperoleh kesimpulan yaitu respon peserta didik terhadap media pembelajaran powtoon adalah sangat baik.

Tahap terakhir adalah penyebaran (disseminate). Video pembelajaran ini akan diunggah ke dalam situs web yaitu youtube dengan link https://youtu.be/LdrX8UZq3Iw. Media pembelajaran powtoon berbasis saintifik ini diunggah ke youtube bertujuan agar video pembelajaran bisa diakses secara mandiri dan bebas, baik oleh guru maupun peserta didik yang membutuhkan materi tersebut. 


\section{Pembahasan}

\section{Kelayakan Media Pembelajaran Powtoon Berbasis Pendekatan Saintifik}

Kelayakan media pembelajaran dapat dilihat dari hasil validasi materi, validasi media, dan validasi bahasa. Perolehan rata-rata validasi materi yaitu $80 \%$ dalam kategori layak, perolehan rata-rata validasi media yaitu $81,18 \%$ dalam kategori sangat layak, perolehan rata-rata validasi bahasa yaitu $94 \%$ dalam kategori sangat layak, dan perolehan jumlah rata-rata keseluruhan hasil validasi adalah $85,06 \%$ dalam kategori sangat layak.

Berdasarkan hasil telaah ahli materi, terdapat beberapa perbaikan antara lain 1) peta konsep menjadi lebih sistematis agar lebih mudah untuk dipahami peserta didik, 2) soal pada poin diskusi terlalu luas cakupannya sehingga perlu difokuskan agar diskusi peserta didik berjalan lebih efektif, 3) penambahan rangkuman yang berisi poin-poin penting dari materi yang sudah dijelaskan untuk menambah pemahaman peserta didik.

Menurut hasil analisis materi diketahui bahwa untuk perolehan kualitas isi dan tujuan $80 \%$, perolehan kualitas instruksional $80 \%$, dan perolehan kualitas teknis $80 \%$. Sehingga total rata-rata keseluruhan aspek diperoleh sebesar $80 \%$ dalam kategori layak. Dari analisis data tersebut diperoleh kesimpulan bahwa materi dalam media pembelajaran powtoon layak untuk digunakan.

Berdasarkan hasil telaah ahli media maka terdapat beberapa perbaikan antara lain 1) penambahan durasi antar slide, 2) penyesuaian bentuk font menjadi lebih formal agar mudah terbaca, 3) warna font menghindari warna merah, 4) penambahan slide pembuka yang berisi pembukaan dan target sasaran media pembelajaran.

Menurut hasil analisis media diketahui bahwa untuk perolehan kualitas teknis sebesar $81,67 \%$ dan perolehan kualitas instruksional sebesar $80 \%$. Sehingga total rata-rata keseluruhan aspek diperoleh sebesar $81,18 \%$ dalam kategori sangat layak. Dari analisis data tersebut diperoleh kesimpulan bahwa media powtoon sangat layak untuk digunakan.

Berdasarkan hasil telaah ahli bahasa maka terdapat beberapa perbaikan antara lain 1) pemilihan kata menjadi lebih efektif, 2) pemakaian tanda baca dan huruf kapital disesuaikan dengan aturan EYD sehingga mempermudah pemahaman peserta didik.

Menurut hasil analisis bahasa diperoleh bahwa total rata-rata keseluruhan yaitu 94\% dalam kategori sangat layak. Sehingga diperoleh kesimpulan bahwa penggunaan bahasa dalam media pembelajaran powtoon sangat layak untuk digunakan.
Penelitian dari (Arnold 2018) menjelaskan bahwa persentase rata-rata keseluruhan validasi adalah $89,2 \%$. Sehingga dapat dinyatakan bahwa pengembangan media pembelajaran video animasi powtoon sangat layak untuk diterapkan dalam proses belajar mengajar pada mata pelajaran pelayanan penjualan.

Berdasarkan perolehan hasil analisis data, jumlah rata-rata validasi sebesar $85,06 \%$. Sehingga kesimpulan yang diperoleh yaitu media pembelajaran powtoon berbasis pendekatan saintifik pada mata pelajaran ekonomi dinyatakan sangat layak digunakan sebagai media pembelajaran.

\section{Kepraktisan Media Pembelajaran Powtoon Berbasis Pendekatan Saintifik}

Kepraktisan media pembelajaran dapat dilihat melalui respon peserta didik. Hal tersebut diperoleh melalui ujicoba produk kepada 20 orang peserta didik di kelas X IPS 2 MAN Sidoarjo. Peserta didik diminta untuk mengamati video pembelajaran powtoon, kemudian mengisi angket respon yang telah disediakan terkait dengan kesan atau ketertarikan mereka pada media pembelajaran.

Selanjutnya hasil angket respon peserta didik dilakukan analisis berdasarkan skala guttman dan diperoleh bahwa total rata-rata keseluruhan hasil angket dari respon peserta didik yaitu sebesar 95,5\% dalam kategori sangat layak. Sehingga diperoleh kesimpulan yaitu respon peserta didik terhadap media pembelajaran powtoon adalah sangat baik.

Hasil dari respon peserta didik kelas X IPS 2 MAN Sidoarjo menunjukkan bahwa mereka merasa tertarik dan termotivasi untuk belajar, kegiatan pembelajaran menjadi tidak membosankan, peserta didik juga aktif melakukan kegiatan tanya jawab terkait dengan materi bank sentral dan sistem pembayaran, dan peserta didik lebih mudah untuk memahami materi yang ditampilkan pada media pembelajaran powtoon, sehingga hasil belajar akan meningkat.

Hamalik (1986) memaparkan bahwa penggunaan media didalam proses belajar bisa meningkatkan keinginan dan minat untuk belajar, menumbuhkan rangsangan dan motivasi belajar, serta mempengaruhi psikologi peserta didik. Penggunaan media belajar dapat meningkatkan keefektifan pembelajaran serta dapat menyampaikan pesan dan isi pelajaran kepada peserta didik (Arsyad 2017).

Respon peserta didik terhadap media pembelajaran bisa dilihat melalui ekspresi, pendapat langsung dari peserta didik terkait ketertarikannya terhadap media, mempermudah dalam memahami 
pesan dan materi yang disampaikan melalui media, dan bagaimana motivasi peserta didik setelah penerapan pembelajaran menggunakan media tersebut (Susilana dan Riyana 2009).

Berdasarkan hasil analisis tersebut, maka diperoleh kesimpulan yaitu 1) peserta didik yang sebelumnya kurang memperhatikan saat proses pembelajaran, menjadi lebih aktif dengan media pembelajaran powtoon, 2) peserta didik lebih termotivasi untuk belajar, 3) peserta didik lebih memahami materi, sehingga bisa meningkatkan hasil belajar. Maka hal tersebut membuktikan media pembelajaran powtoon berbasis pendekatan saintifik yang telah dikembangkan memenuhi kriteria kepraktisan dengan interpretasi sangat layak.

\section{Keefektifan Media Pembelajaran Powtoon Berbasis Pendekatan Saintifik}

Keefektifan media pembelajaran dapat dilihat melalui hasil belajar. Pembelajaran dapat dikatakan efektif apabila nilai ketuntasan klasikal yang dicapai oleh peserta didik sebanyak $75 \%$ dari total keseluruhan. Sedangkan nilai KBM sekolah adalah sebesar $\geq 80$.

Sebelum menggunakan media pembelajaran powtoon berbasis pendekatan saintifik, peserta didik diberikan soal pretest. Hasil dari analisis data pretest menunjukkan jumlah peserta didik yang tuntas yaitu $55 \%$ atau sebanyak 11 orang, dengan perolehan nilai terendah 40 dan perolehan nilai tertinggi 90.

Setelah menggunakan media pembelajaran powtoon berbasis pendekatan saintifik, peserta didik diberikan soal posttest. Hasil dari analisis data posttest menunjukkan jumlah peserta didik yang tuntas yaitu $90 \%$ atau sebanyak 18 orang, dengan perolehan nilai terendah 60 dan perolehan nilai tertinggi 100 .

Berdasarkan analisis data yang dilakukan, soal yang paling banyak benar jawabannya adalah soal nomor 3 tentang tujuan tunggal Bank Indonesia yaitu sebesar $100 \%$ peserta didik menjawab dengan benar. Tingkatan pemahaman konsep soal ini adalah C1 yaitu pengetahuan. Sedangkan soal yang seringkali jawabannya salah adalah soal nomor 7 tentang peran Bank Indonesia dalam sistem pembayaran yaitu sebesar $40 \%$ peserta didik yang menjawab salah. Tingkatan pemahaman konsep soal ini adalah C3 yaitu penerapan. Hal itu bisa terjadi karena peserta didik kurang dalam memahami soal yang diberikan dan mudah terkecoh dengan bentuk soalnya.

Sehingga diperoleh kesimpulan bahwa setelah menggunakan media pembelajaran powtoon, hasil belajar peserta didik mengalami peningkatan yang signifikan, yaitu sebesar 35\%. Sebelum menggunakan media pembelajaran, peserta didik yang tidak tuntas sejumlah 9 orang. Selanjutnya setelah menggunakan media pembelajaran, terjadi penurunan yaitu hanya 2 orang saja yang tidak tuntas.

Berdasarkan analisis data diatas, membuktikan jika media pembelajaran powtoon berbasis saintifik adalah media yang efektif dan layak untuk diterapkan. Ketuntasan ini membuktikan bahwa media pembelajaran powtoon yang telah dikembangkan bisa membantu peserta didik untuk memahami materi bank sentral dan sistem pembayaran.

Hal tersebut sesuai dengan pendapat B. Uno dan Mohamad (2012) dalam (Andrianti, Susanti, dan Hudaidah 2016) pembelajaran dapat dianggap efektif jika nilai yang dicapai oleh peserta didik diatas nilai rata-rata atau sudah melebihi dan di atas batas kompetensi yang sudah dirumuskan sebelumnya.

Selain itu menurut Mayer \& Moreno (2002) dengan menggunakan animasi didalam proses belajar mengajar akan sangat membantu meningkatkan efektifitas dan efisiensi, sehingga hasil pembelajaran mengalami peningkatan. Selain itu penggunaan media pembelajaran, khususnya animasi bisa membangkitkan motivasi dan ketertarikan peserta didik untuk mengikuti proses pembelajaran.

\section{PENUTUP}

\section{Simpulan}

Berdasarkan hasil penelitian di atas, maka dapat disimpulkan bahwa:

1. Media pembelajaran powtoon berbasis pendekatan saintifik yang telah dikembangkan oleh peneliti layak untuk digunakan. Kelayakan media diperoleh dari nilai rata-rata validasi materi, validasi media, dan validasi bahasa dengan perolehan rata-rata sebesar $85,06 \%$ dalam kategori sangat layak.

2. Media pembelajaran powtoon berbasis pendekatan saintifik yang telah dikembangkan oleh peneliti praktis untuk digunakan. Kepraktisan media dapat dilihat melalui respon peserta didik dengan perolehan rata-rata respon peserta didik sebesar $95,5 \%$ dalam kategori sangat layak.

3. Media pembelajaran powtoon berbasis pendekatan saintifik yang telah dikembangkan oleh peneliti efektif untuk digunakan. Efektifitas media dapat dilihat melalui hasil belajar peserta didik dengan persentase ketuntasan sebesar 90\%, hasil tersebut merupakan peningkatan daripada hasil pretest yang memiliki persentase ketuntasan sebesar 55\% saja. 


\section{Saran}

Perlu dilakukan pengembangan media pembelajaran powtoon berbasis pendekatan saintifik pada materi dan mata pelajaran lainnya, dalam membuat media pembelajaran ini guru harus menguasai laptop dan internet, tidak semua sekolah mempunyai lcd, speaker, dan jaringan internet atau wifi.

\section{DAFTAR PUSTAKA}

Andrianti, Yeni, L.R. Retno Susanti, dan Hudaidah. 2016. "Pengembangan Media Powtoon Berbasis Audiovisual pada Pembelajaran Sejarah." Jurnal Criksetra 5(9): 58-68.

Ariyanto, Rio, Sri Kantun, dan Sukidin Sukidin. 2018. "Penggunaan Media Powtoon Untuk Meningkatkan Minat Dan Hasil Belajar Siswa Pada Kompetensi Dasar Mendeskripsikan Pelaku-Pelaku Ekonomi Dalam Sistem Perekonomian Indonesia.” Jurnal Pendidikan Ekonomi: Jurnal Ilmiah Ilmu Pendidikan, Ilmu Ekonomi dan Ilmu Sosial 12(1): 122-27.

Arnold, Raffaello Bryan. 2018. "Pengembangan Media Pembelajaran Video Animasi Powtoon Pada Mata Pelajaran Pelayanan Penjualan di SMK Ketintang Surabaya." Jurnal Pendidikan Tata Niaga (JPTN) 06(04): 145-50.

Arsyad, Azhar. 2017. Media Pembelajaran. Revisi. Jakarta: PT Raja Grafindo Persada.

Ernalida et al. 2018. "Powtoon: Media Pembelajaran berbasis Teknologi Informasi sebagai Upaya dalam Menciptakan Pembelajaran yang Menarik dan Kreatif." Jurnal Logat 5(2): 132-37.

Mamin, Ratnawaty, Rifda Nur, dan Hikmahwati Arif. "Efektivitas media pembelajaran video tutorial terhadap hasil belajar mahasiswa pada Matakuliah IPA Sekolah." : 348-52.

Mayer, Richard E., dan Roxana Moreno. 2002. "Animation as an aid to multimedia learning." Educational Psychology Review 14(1): 87-99.

Mulyasa, E. 2013. Standar Kompetensi dan Sertifikasi Guru. Bandung: PT Remaja Rosdakarya.

Munir. 2012. 58 Antimicrobial agents and chemotherapy Multimedia Konsep \& Aplikasi Dalam Pendidikan. Bandung: Alfabeta.
Pangestu, Marta Dwi, dan Achmad Ali Wafa. 2018. "Pengembangan multimedia interaktif powtoon pada mata pelajaran ekonomi pokok bahasan kebijakan moneter untuk siswa kelas xi ips di sma negeri 1 singosari." Jurnal Pendidikan Ekonomi 11(1): 71-79.

Ponza, Putu Jerry Radita, I Nyoman Jampel, dan I Komang Sudarma. 2018. "Pengembangan Media Video Animasi pada Pembelajaran Siswa Kelas IV di Sekolah Dasar." Jurnal Edutech Undiksha 6(1): 9-19.

Riduwan. 2016. Skala Pengukuran Variabel-Variabel Penelitian. Bandung: Alfabeta.

Sadiman, Arief S., R. Rahardjo, Anung Haryono, dan Harjito. 2014. Media Pendidikan. Jakarta: PT Raja Grafindo Persada.

Sari, Mafita, dan Suci Rohayati. 2016. "Pengembangan Media Pembelajaran Powtoon Sebagai Bahan Pengamatan Dalam Implementasi Pendekatan Saintifik Pembelajaran Dasar-Dasar Perbankan.” Jurnal Pendidikan Akuntansi (JPAK) 5(1): 1-7.

Susilana, Rudi, dan Cepi Riyana. 2009. Media Pembelajaran. Bandung: CV Wacana Prima.

Syifaunnur, Hafidh. 2015. "Pengembangan Dan Analisis Kelayakan Multimedia Interaktif 'Smart Chemist' Berbasis Intertekstual Sebagai Media Pembelajaran Kimia SMA.”

Trianto. 2007. Model Pembelajaran Terpadu dalam Teori dan Praktek. Jakarta: Prestasi Pustaka. 